\title{
ЭВОЛЮЦИЯ ЛЕКСИЧЕСКОЙ СИСТЕМЫ. СТАРЕНИЕ И ИСЧЕЗНОВЕНИЕ СЛОВ И ЕГО ПРИЧИНЫ
}

\author{
ВЛАДИМИР ШАПОШНИКОВ \\ Московский государственный психолого-педагогический университет \\ Факультет иностранных языков \\ Кафедра лингводидактики и межкультурной коммуникации \\ ул. Василия Ботылева, д. 31, 121500, Москва, пос. Рублево, Россия \\ e-mail: vladimirshaposhnikoff@yandex.ru \\ ORCID: https://orcid.org/oooo-ooo1-7302-1345 \\ (получено 12.08.2018; принято 26.09.2018)
}

\section{Abstract \\ Lexical system evolution. \\ Words' obsolescence and disappearance, and their causes}

This paper discusses the functioning and development of language on the material of the modern Russian language. The author analyzes the vocabulary and evolution of the lexical system, considering such phenomena as obsolescence and disappearance of words from the language. The factors and reasons for eliminating certain words are considered. The fundamental causes of words' obsolescence and their elimination from the language system are analyzed. The author identifies the relationship between the obsolete and the contemporary language material. The degree and stages of diachronic processes and their results are noted.

\section{Key words}

Language sign, language development, meaning, obsolete lexicon, word disappearance, causes of lexical exchanges, changes in the Russian language. 


\section{Резюме}

В статье рассматривается функционирование языка и языковое развитие. Анализируется лексика и эволюция лексической системы. Выявляется устаревание, уход и исчезновение слов из языка. Рассматриваются факторы и причины устранения слов. Анализируются основополагающие причины старения и устранения слов из языковой системы. Выявляются соотношения уходящего языкового материала с существующим материалом. Отмечаются степень, этапы и стадии диахронических процессов и их результаты. Описывается материал современного русского языка.

\section{Ключевые слова}

Языковой знак, развитие языка, значение, устаревшая лексика, исчезновение слов, причины лексических изменений, изменения в русском языке.

Проблема эволюции языка как средства человеческого общения издавна привлекает внимание многих исследователей. В языке все время идет процесс появления одних слов и утраты других. В языковой системе закономерно деление лексики по способу бытования единиц на активный и пассивный состав. Изменяют свой системный статус, выходят из активного употребления и существуют в этом качестве в языке устаревшие слова, известные как историзмы и архаизмы.

Лексика выходит из употребления и происходит выпадение, исчезновение слов из языка. Это первый, исходный акт эволюции лексической системы. Каковы его причины и структурные основания? Строится диссипативная динамическая модель эволюции языковых знаков, удовлетворяющая принципу наименьшего действия. Таким образом освещается жизненный цикл языковых знаков.

Примечателен путь слова разронять. Оно представляет результативно-распределительный способ действия, одновидовой глагол. Слово употреблялось в XIX-XX вв., а также ранее (Словарь русского языка XI-XVII в.); хотя оно и не было активным (например, Частотный словарь русского языка 1977 г. его не включает), но выражало релевантное понятие. Это слово относилось к литературной лексике. Затем из ее состава сначала перешло в сниженный регистр языка, ТСУш: (разг.) 'выронить, уронить в несколько приемов много чего-н.' Разронять все деньги. Впоследствии слово функционировало в устном бытовом просторечии, каковым путем происходит сужение сферы употребления и стилевой сферы.

Специфичен тип его значения: слово выражало внутреннюю оппозитивность явления и парцеллированность действия. Специфично его содержание: слово было эмоциональным, с небольшим оттенком экспрессивности.

Со временем слово теряет свое место в словарях. МАС (1984): разг., разронял стаканы (И. Гончаров, Обломов); разроняли иветы по всей сиене (А. Блок, Балаганчик). Это последнее употребление в сущности представляет другое значение. 
НСРЯ (2000) подает глагол без стилевой пометы, формулируя два значения, но без иллюстративного материала. СОШ (1993) дает одно значение с иллюстрацией: разронял все свертки - несколько иное значение, куда входит компонент 'полностью, все'. БТСРЯ (1998) фиксирует разронять как «уронить одно за одним в несколько приемов (все, многое). Р. все монеты, $P$. все покупки, $P$. с подноса все ложки, Р. иветы по сиене». Этот словарь не дает новых примеров употребления, но повторяет старый материал. Глагол предстает многовалентным, в том числе с валентными связями «откуда» и «где» - семантическими ролями начальной точки и конечной точки / места. Актуализатором «все» выносится компонент полного, исчерпанного количества - семантическая роль количественного или качественного параметра, аналогичная семантике, имеющейся в слове приставки. ТСРЯ под ред. Дмитриева (2003) это слово не фиксирует.

Слов-синонимов с минимальными различиями в значениях к «разронять» нет. Следовательно, это не архаизм как единица лексики современного русского языка. Понятийной замены в русском языке нет - это и не историзм.

Слово затухает в узусе, исчезает из языка. НКРЯ находит только один пример реального употребления слова в XX в.: От старания не разронять <печенье > и от удовольствия язык у него был высунут (Кнорре, Орехов, 1968). Ранее этого отыскивается употребление: И он внезапно ударил свою супругу по тииу, отчего та разроняла битки по полу и взревела (Булгаков, Мастер и Маргари$m a)$, но не вошедшее в окончательный текст романа.

В данное семантическое поле входят и устойчиво существуют в русском языке слова: уронить, выронить, обронить, обозначающие движение вниз, выпадение. Они являются друг по отношению к другу синонимами, выражающими одно понятие. Это более абстрактные слова, с меньшим количеством внутренних признаков значения.

Существует слово попадать 'упасть в большом количестве или один за другим'. Это глагол результативного способа действия. По отношению к отмечаемому разронять - это конверсив, представляющий собой субъектно-объектное преобразование.

Существовало слово данного семантического поля поронять 'уронить в большом количестве’. Оно сужало сферу употребления. ТСУш: (разг.) уронить в большом количестве. Это слово устаревает: его отмечает МАС (1984) со старыми примерами из Гоголя, Лескова, в НСРЯ (2000) лексема появляется без иллюстративного материала, а ТСРЯ под ред. Дмитриева (2003) поронять не фиксирует.

Уходит слово сронить. ТСУш: сбросить, уронить с чего-н. МАС (1984) отмечал его как разговорное, цитируя Толстого, Зворыкина. СОШ (1993), НСРЯ (2000), ТСРЯ (2003) его уже не отмечают. Лексему давал БТСРЯ (1998) с несколько искусственным речением: Не срони пепел на ковер, представляющим иной смысл слова.

При анализе языковых причин изменения функционирования единицы указание на внутреннюю форму слова, пространственное объяснение судьбы «разронять» (несоответствие значений морфем в структуре слова) не вполне работает. Основные значения приставки раз-: 'разделение, распределение, 
распространение действия, движение из какой-л. точки, уничтожение, интенсивность' В словах разронять и попадать у приставок есть парцеллятивные значения, но нет подобного корню значения направленности движения вниз. Комбинация приставки раз- и корневого значения движения вниз слова разронять начинала обозначать распространение действия по поверхности, например: Дамы разроняли изветы по всей сиене (Блок, 1910); И даже этот дважды идиот Твид разронял свои слюни по всему портовому спуску (Паустовский, 1925). Однако и в этом значении разронять выпадает из языка. Наоборот, в слове сронить приставка имеет значение движения сверху вниз, аналогичное значению корня, однако при этой гармоничности морфемных значений слово сужает сферу употребления и уходит из языка.

Выделяется другой факт диахронии. Из существовавших синонимических рядов уходят слова со значением 'сомкнуть и преградить доступ': отворить, растворить, затворить, притворить. Это архаизмы. Заменами им в современном русском языке являются слова: открыть, раскрыть, закрыть, прикрыть; распахнуть, замкнуть.

Здесь тот же функционально-стилевой путь угасания слова. Образуется просторечность и устарелость материала, хотя СОШ (1993), НСРЯ (2000) подают лексемы: затворить/-ять, отворить, притворить, растворить, растворять.

В общем и целом, совершается уход групп слов из русского языка. Это отмирание слова. Что такое «отмирать» применительно к слову? В связи с этим стоит вопрос, как действительно соотносятся понятия активный и пассивный словарь языка. Как и насколько точно можно отметить, в каком из системных разделов находится данное слово в данный момент языкового существования? Всегда ли наступает окончательный момент, когда слово исчезает из языка совсем? Можно ли считать исчезнувшими из русского языка слова епанча, гридень, зипун, охабень, ратай либо панама (мошенничество), папаниниьь, паразитство, примиренеи, партминимум, партмаксимум, парторг, всевобуч, бабзавуч и т.п.? Есть масса литературных текстов, где эти слова фигурируют, есть словари разных типов, в которых они зафиксированы, а при этом их доступность и известность в информационном обществе стала более широкой. Есть также и некоторое число людей, которые могут их знать так или иначе. Представительны в коммуникативном пространстве такие советские неологизмы, как большевик, колхоз, комсомолеи, пионер. Весь процесс выпадения знака из употребления идет более медленно, чем рождение новых значений.

Ушли из русского языка весьма старые слова: лихоимеи, барышник, кулак, лапотник, подкулачник, кустарь, скопидом, ведро, духом и под.; поречник (бурлацкая тропа), урильник (ночной горшок). Ушли новые, недавнего происхождения слова: спеи, иелинник, мастак (простореч.), принудиловка, прогрессивка.

Наблюдается уход слов: домоуправление, управдом/домоуправ, сельпо, жировка, хозрасчет, соисоревнование, двурушник, двурушничество. Так же уходят слова: ударник, ударнииа, ударничество, разукрупнить, разукрупнение (ТСУш.: нов. офиц.). 
Ушли слова социально-политической сферы, обозначавшие особые реалии: красноблотеи, комсомолеи, юнкор, юннат, рабкор, тишенеи, лишенка, стахановеи, стахановеи, челюскиниы, содмилеи, бригадмилеи, октябренок.

Устранились также слова специфического предметного участка: дербальзнуть, дерябнуть, налимониться (простореч.).

Устранилось упомянутое слово детализованного значения разронять. Исчезает слово пробрать/nробирать с его несколькими значениями. Ушли некоторые другие актуальные глагольные и отглагольные образования: осклабить/-ся, осклаблять, осклабляться (НСРЯ), разымчивый (ТСУш.: устаревш. и областное), разруб, разращать (ТСУш.: книжн. редко) несов. вид к разрастить, разращение (книжное), разращенный (книжн.), размокропогодить/-ся (разг.), размаять, размаянный (разг.), разогорчить/-ать, размицкать/-ся, разведриться, разлизать, разлимонить/-ся, разнствовать, раскабалить/-ся, раскупоривать, рассевать, рассрочить (распределить на несколько сроков), расстричь, разбраниться, побраниться, выбраниться, выбранить. Ушли слова распределительного значения с другой приставкой: переарестовать (всех или многих, одного за др.), перебраковать, перегасить, перезанимать, перезябнуть, перекрасть, перемирить, перемутить, перенумеровать, перепрятать. Утратило прямое значение слово растерять. Ушли глаголы с приставкой no-: -брать, -гнить, -наглеть, -мучивать.

Отмечен уход слов в составе лексико-грамматического класса. Таков путь слов из служебной части речи - усилительных частиц и некоторых других: $a б b$, $\kappa a б b$, вить, бишь, нехац̆, се, чу, инда, чай. Весьма устаревшие в современном русском языке частицы: ажно, ан, вишь, ужель, -ma, me, то, -с. Например, АТОС фиксирует вишь простореч., но иллюстрирует старым материалом Грибоедова, Гончарова, Исаковского. Устаревшими являются частицы: авось, право, то бишь, аж, небось, дескать, де, мол, таки (Шапошников, 2017).

В целом количество ушедших из современного русского языка слов большое.

Рассмотрим основные причины ухода слов из языка. Прежде всего это социальные причины - языковые процессы, обусловленные общественными изменениями.

1. Исчезновение реалий, предметов, обозначавшихся словами: грампластинка, проигрыватель, радиола; комсомолеи, хозрасчет, прогрессивка, принудилов-

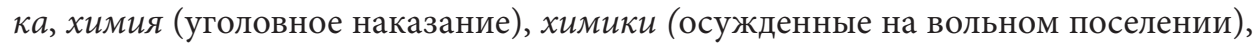
рабкор, селькор, кинопередвижка, радиолампа, продотряд, продразверстка, парторг, партактив; барка, барочник, золотарь, лабаз, ладонка, комод, трубочист, лоскутник, иелинник; компаунд.

2. Устранение понятий, выражавшихся словом: бархатник, барышинк, сознательность, кулак, кулачество, раскулачить, переселенеи, расселенеи, подкулачник, расстегай (сарафан), расстрига, общественник, лабазник, лавочник, лабазныц̆, лавочка, лаж (в торговле), лажныци, Целина (целинные земли на юговостоке СССР, осваивавшиеся и заселявшиеся по госпрограмме), иелинный, иелинник. Эти понятия системно проектировались, а ныне не проектируются.

Уход этого ряда лексем обусловлен устранением самой мыслительной среды, в которой создавались и функционировали выражаемые ими понятия. Ха- 
рактерны некогда актуальные слова: перегибщик '(нов. разг.) тот, кто допускает перегибы'; ударник '1. деталь оружия, 2. военнослужащий особых, ударных частей в период февр. рев. 1917 (истор.), 3. передовой работник социалистического производства, перевыполняющий нормы, активно овладевающий техникой и показывающий образцы производственной дисциплины (нов.)'; ударница, ударничество, ударност (ТСУш.). Эти слова были порождены определенной социально-нравственной средой. Ныне же эти слова с их созданными значениями ушли из языка. Тот же путь и основа устранения слов: загиб, перегиб, обуржуазить, обуржуазиться, обуржуазивание, орабочить, орабочение и т.п.

3. Уходят из состава языка такие слова, как: лакей (домашний слуга при господах (дореволюц. и загран.), лакейский; компаньонка (женщина, нанимавшаяся в барские дома для развлечения или сопровождения дам или молодых девиц (истор.); кокотка (женщина легкого поведения, живущая на содержании у мужчин) (ТСУш.). Они уходят при изменении общественных отношений и появлении социальной оценки, связывающейся с их содержанием. По этой причине слово слуга устраняется из системы активной лексики, переходя в пассивный запас и переносно-обобщенный смысл; то же изменение: хозяин (частный наниматель), приказчик, лакей. Ушли из употребления слова ограниченного предметного участка: дьячок, ермолка, поп, поповна, поповка (место у церкви, где живет церковный причт), служка; каллиграф, истмат (исторический материализм).

4. Такие социально не маркированные лексические единицы: громоздить, разбранить (разг.), выбранить, разброска (разг.), развалка (прост.), разбросить (разг.), разгородить (прост.), раздружить, разлакомить (разг.), подружить, разлетайка, разлимонить, налимониться, навыкать, разманить, размаять, размаяться, намориться, размоина, размучить, размиєкать, разнизать, разнизаться, растеплить (растрогать) - это общеупотребительные слова, фиксировавшиеся ТСУш. и относившиеся к активному лексическому запасу в XX в. Ныне они ушли из языка, как и слова несколько более узкого употребления, фиксировавшиеся ТСУш.: брататься, разбрататься (областное), разведрить, раздорожье, разлогий (областное), разгасить (разморить) и т.п. Все они одинаковы по внутренней структуре и по внутренней форме значения. Очевидно, что соотношение внутренней структуры и внутренней семантической являются причиной ухода данных слов из языковой системы. Словообразовательное переоформление признаковыми номинациями плана выражения, замена отдельных знаменательных признаковых номинаций служебно-признаковыми номинациями становится для каждого из значений слов в среднем определяющим в связи с их общим старением, и при этом обусловливается общей абстрактизацией, депредметизацией и окачествлением, а также субъективизацией их значений в их истории.

5. Фактором сохранности либо ухода слов является когнитивный характер значения языковой единицы. Логическое по преимуществу, логико-предметное или эмоциональное, экспрессивное значения являются историческими условиями жизни слова. По этой причине уходят многие лексемы просторечия (см. Шапошников, 2012). 
6. Причину ухода слов можно видеть в отдельных случаях избавления от омонимии. Например: затворить; растворить.

В заключение отметим, что весь процесс выпадения значений знака из употребления идет более медленно, чем процесс рождения новых значений и слов.

\section{Библиография}

Академический толковый словарь русского языка (2013-2017). Т. 1-10. Москва: Наука. Большой толковый словарь русского языка (1998). Санкт-Петербург: Норинт.

Василевич, А. П. (2005). Жизнь после смерти. Заметки о словах, исчезающих из языка. Проблемы прикладной лингвистики. Вып. 2. Москва: Институт языкознания РАН.

Ожегов, С. И., Шведова, Н. Ю. (1993). Словарь русского языка. Москва: Азбуковник.

Словарь русского языка (1984). Т. 1-4. Москва: Русский язык.

Словарь русского языка XI-XVII в. (1975-1999). Москва: Наука.

Толковый словарь русского языка (1939-1940). Т. 1-4. Москва: Советская энциклопедия.

Частотный словарь русского языка (1977). Москва: Русский язык.

Шапошников, В. Н. (1998). Русская речь 1990-х. Современная Россия в языковом отображении. Москва: МГУ.

Шапошников, В. Н. (2012). Просторечие в системе русского языка на современном этапе. Москва: URSS.

Шапошников, В. Н. (2017). Частицы в современном русском языке. Москва: Инфра-М.

\section{Список сокращений}

БТСРЯ 1998 - Большой толковый словарь русского языка. Санкт-Петербург: Норинт, 1998.

МАС 1984 - Словарь русского языка. Т. 1-4. Москва: Русский язык, 1981.

НКРЯ - Национальный корпус русского языка (http://www.ruscorpora.ru/)

НСРЯ 2000 - Новый словарь русского языка. Толково-словообразовательный. Москва: Русский язык, 2000.

СОШ 1993 - Ожегов С. И., Шведова Н. Ю. Толковый словарь русского языка. Москва: Азбуковник, 1993.

ТСРЯ 2003 - Толковый словарь русского языка. Санкт-Петербург: Златоуст, 2003.

ТСУш - Толковый словарь русского языка. Т. 1-4. Москва: Советская энциклопедия, 1935-1940. 